\title{
NEMZETKÖZI RENDÉSZETI FIGYELŐ
}

\section{Beke József, Cieleszky Péter, Nagy Ivett, Fejes Attila, Rompos Éva, Kalmár Ádám, Urbán Ferenc, Lippai Zsolt, Pászti Péter Gergely}

\section{Nemzetközi Rendészeti Figyelő II.}

International Law Enforcement Observer II.

\section{Beke József}

Az érzelmek szabályozása: milyen stratégiát alkalmaznak a tapasztalt bünügyi rendőrök?

Controlling emotions: what strategy do experienced criminal police officers use?

A kihallgatás egy olyan különleges kommunikációs helyzet, amelyben együttmüködő kapcsolatot kell kialakítani többnyire nehéz helyzetben lévő és egyben nehezen kezelhető személyekkel. Mindezt a kihallgatás legfőbb céljának megvalósítása érdekében kell tenni: az elkövetett büncselekményt utólag a valóságnak legmegfelelőbb módon kell rekonstruálni. Felmerül, hogy a kihallgatást végzők ennek során hogyan kontrollálják az érzelmeiket, milyen stratégiákat alkalmaznak? Ahhoz, hogy ezekre a kérdésekre megfelelő választ kapjunk, fontos, hogy elöször megértsük, mit jelentenek az érzelmek és azoknak milyen szabályzási módszerei vannak. Az érzelmek egy olyan rendszert jelentenek, amely affektív, kognitív, fizikai és expresszív komponensekből áll. A cikkben kifejtésre kerül néhány fontos érzelemszabályozási módszer, mint például az elkerülés, a megzavarás vagy az elfogadás. 
Az érzelemszabályozás a mindennapi élethelyzetek kezelésében is fontos szerepet játszik. Gondoljunk csak a magán- és szakmai szférában kialakult stresszhelyzetekre, melyek önmagukban is kihívást jelentek az egyén számára: ha ilyen esetekben nem megfelelő érzelemszabályozási stratégiát alkalmazunk, akkor a szociális kapcsolatokban is könnyen kárt lehet okozni.

\section{A kihallgató személy jelentösége a rendörségi kihallgatás szempontjából}

A rendőrségi kihallgatás egy olyan különleges kommunikációs helyzet, amikor egy személyt egy rendőr hallgat ki az „objektív” igazság kiderítése érdekében. Ennek keretében a kihallgató köteles betartani a lefektetett eljárási normákat. A pszichológiai kutatások mára bebizonyították, hogy a kihallgatás céljának elérése döntően függ attól, hogy a kihallgatónak sikerül-e együttmüködésen alapuló kapcsolatot kialakítania a kihallgatandó személlyel, legyen az tanú vagy vádlott.

\section{Érzelmek és érzések}

Lényeges néhány definíció tisztázása mielőtt az érzelmek szabályzásának kérdéseivel foglalkoznánk. Először is el kell határolni egymástól az érzelmek és az érzések kategóriáját. A kettő közül az érzelem a magasabb rendü kifejezés, amely különféle összetevőkből áll. Az érzés (vagy hangulat) az érzelem affektív összetevője, mely magában foglalja a szubjektív tapasztalást.

\section{Az érzelem szabályzásnak módja, stratégiái}

A stratégiák az érzelem megjelenésének időbeli lefutása szerint osztályozhatók, ahogy azt James J. Gross javasolja az általa készített folyamatmodellben: az egyén viszonylag korán, már az érzelem megjelenésekor aktívan beavatkozhat helyzetválasztással vagy megváltoztatott szempontokat véve figyelembe. Egy másik lehetőség az, ha a figyelmet a helyzet egyes aspektusaira összpontosítják és szükséges esetben az egyén azokat átértékeli. Fontos, hogy a stratégiák a folyamat későbbi szakaszában is felhasználhatók a már bekövetkezett érzelmi reakciók megváltoztatására. Gross rendszerét sok kritika érte elsősorban amiatt, hogy nincs értelme az egyes stratégiákat határozottan az időbeli folyamatokhoz rendelni. 
Nincsenek eredendően jó vagy rossz érzelemszabályozási stratégiák, de alkalmazásukat az adott szituáció feltételeitől függően értékelni kell. Bizonyos körülmények között a legmegfelelőbb lehet elkerülni a helyzet kiváltó okait. Ha azonban ez nem lehetséges, felmerül a kérdés, hogy mely egyéb stratégiák vezetnek a cél eléréséhez. Itt fontos figyelembe venni, hogy a kiválasztott stratégia milyen hatással lesz rövid és hosszú távon.

Tapasztalt bünügyi nyomozók érzelmi szabályozása az emberölések és a szexuális jellegü büncselekményekre vonatkozó kihallgatások során

David Grießig 2017-ben összesen hat nyomozóval készített interjúkat. Három nő és három férfi nyomozó, mindannyian a berlini Bünügyi Nyomozói Hivatal (Landeskriminalamt Berlin) személy elleni büncselekményekkel kapcsolatos munkájában vesznek részt. A legfiatalabb 28 éves, míg a legidősebb 51 éves, az átlagéletkoruk 39 év. Hárman az emberölésekkel, míg hárman a szexuális jellegü büncselekményekkel kapcsolatos nyomozásokban vesznek részt. Mind a hat személy legalább hároméves tapasztalattal rendelkezik a kihallgatások területén. A szakértői interjúk során az elsődleges cél annak kiderítése volt, hogy a kihallgatások alatt milyen szituációk váltanak ki érzelmeket bennük, és ezeket hogyan kezelik, vagyis mely érzelemszabályozási stratégiákat használják az adott helyzetekben. Első lépésként a nyomozók véleményét kérdezték a kihallgatások szakmai lefolytatásáról. Ennek célja az volt, hogy feltárják a szakmai célkitüzéseiket.

A hat interjúalany a stratégiáknak egy meglehetôsen széles skáláját alkalmazza, ugyanakkor mindannyian jelentős követelményeket támasztanak saját érzelmeik szabályzásával szemben. Mindannyian osztoznak abban, hogy a kihallgatás céljának elérése - vagyis a megbízható információk megszerzése - csak akkor lehetséges, ha megteremtik a kommunikáció alapját a másik féllel. Emiatt nagyon fontos, hogy a kihallgatás előtt alaposan tanulmányozzák az adott személyről és az esetről rendelkezésre álló információkat, mely egyfajta többlettudást eredményez. Mindez erősen csökkenti a kihallgatás során fellépő erős érzelmeket, például a hazugságokkal való szembenézést vagy a tiszteletlenséget. Ha a kihallgatóknak sikerül ezt a szakmai szerepet kialakítani, az növelheti a lehetőséget a másik fél szemszögének átvételére és megismerésére, valamint a szükséges távolságtartás és az empátia kombinációjának kialakítására. Ez az elfogadó attitüd segíthet abban is, hogy megértsük, a kihallgatás során nehezen elfogadható viselkedés nem a kihallgató ellen irányuló cselekvés, hanem az a kihallgatott gyakran zavart 
személyiségfejlődésének eredménye. Még abban az esetben is, ha a kihallgató olyan erős érzelmeket észlel magán a kihallgatás során, mint például a harag. Az érzelmi kontroll helyreállhat a viselkedés tudatos átértékelésével. Emellett hasznos a kihallgatás lefolytatásának megtanult eljárási rendjére is összpontosítani. Fontos, hogy ne feledkezzünk meg a kihallgatás utáni fázisról sem: a kihallgatás során elfojtott érzelmek a kihallgatás befejezése után megoszthatók a kollégákkal. Értelemszerűen az érzelmeket kiindulópontként kell használni az önreflexióhoz, hiszen így formálhatják saját szakmai fejlődésüket. Szükséges volna, hogy mindezt szisztematikusan alkalmazzák a rendőri gyakorlatban, például kollegiális vagy szakértők által vezetett felügyelet útján, a kihallgatók - akár egész életen át tartó - tanulási folyamatának támogatása érdekében.

\section{Felhasznált irodalom}

Sticher, B. \& Grießig, D. (2019). Emotionsregulation und Vernehmung. Welche Strategien verwenden erfahrene Kriminalbeamtinnen und beamte? SIAK-Journal, 1, 39-50.

\section{Cieleszky Péter}

\section{A spektakuláris hatalom és az erőszak (társadalmi) legitimációja}

\section{The (social) legitimacy of spectacular power and violence}

A Collins és Rothe szerzőpáros tanulmánya 2019-ben megjelent könyvük gondolati ívét előlegezi meg. A szerzők lényegében azt mutatják be, hogy az amerikai neoliberális kapitalizmus világában a társadalom hogyan viszonyul az állami erőszak megnyilvánulási formáihoz. Utalnak arra, hogy az általuk bemutatott viszonyrendszerben lényegében egy hatalmi legitimációs ciklus fedezhető fel, amelyben a katonai bemutatók, légiparádék és a szórakoztatóipar egyéb termékei szimbólumokká válnak, és nacionalista-nemzetbiztonsági ideológiába ágyazottan megerösödnek. A társadalom tehát az elfogadáson túlmutató cselekvő közreműködéssel - a fogyasztás folyamatos fenntartásával és kielégítésével - lényegében az állami erőszak újratermelődését támogatja, így legitimálva azt. Látszólagos az ellentmondás, miszerint az állami szerepvállalás mérséklése irányába mutató neoliberális eszmék talaján, éppen a piaci érdekeknek a gazdaság egy adott szegmensében megfigyelhető érvényesülésén keresztül támogatott az állam - jelen esetben az állami erőszak - hegemóniája. 
A neoliberális gondolat mögötti gazdaságpolitika egyik alaptétele ugyanis az állami újraelosztás lebontásával megvalósított, (állami) beavatkozásoktól mentes szabadpiaci versengés megteremtése, a hatékonyság növelése érdekében. Másképpen fogalmazva: a neoliberális gondolat szerint a fejlődés motorja a szabadpiac minél zavartalanabb múködésének biztosítása - legalábbis a piaci fundamentalista közgazdászokat tömörítő Mount Pelerin Társaság ezt az álláspontot képviselte.

Ezzel szemben azt látjuk, hogy az állam a fenntartója, megrendelóje annak a hadi ipari komplexumnak (Eisenhower, 1961), amelyre az egykori elnök 1961-es búcsúbeszédében úgy hivatkozik, mint ,politikai, üzleti, katonai és tudományos elitcsoportok együttmüködésének arra a második világháborút követöen intézményesült rendszerére, amely a termelési folyamatokat úgy vonja egyre erösebben befolyása alá, hogy közben a társadalom képtelen ellenörzést gyakorolni felette" (Pogátsa, 2017).

Az ellentmondás tehát látszólagos. Valójában a „foglyul ejtett állam” (captured state) problémájáról van szó. Ennek lényege szerint a gazdasági elit a politikai elitbe fonódik, és ott saját céljait állami akaratként fejezi ki. A gazdasági és politikai elit közötti megkülönböztetés tehát értelmetlenné, a hagyományos értelemben ismert modern polgári állam látszólagossá válik (Rothe \& Collins, 2018). Az elmélet elvezet addig a következtetésig is, hogy éppen a hadi ipari megrendelések és a fegyverkezés biztosítja a gazdasági növekedést (Ruttan, 2006) - alátámasztva a fejlett gazdaságok hadiipar-függőségéről szóló elméleteket. A kutatók ezen a ponton jól látják a média közvéleményformáló hatásának erejét: , $A$ demokratikus ellensúly hiányában egyre inkább önjáró »védelmi« ipar saját expanzióját mind kifinomultabb módszerekkel - nem utolsósorban intenzív médiapropagandával-biztosítja." (Mullen, 2010).

A kutatók felhívják ugyanakkor a figyelmet arra is - legalábbis megközelítésük erre enged következtetni -, hogy ez a ciklus egy spektakuláris értelmezési keretben müködik. Ez ebben az esetben azt jelenti, hogy másról vagy többről van szó, mint puszta közvéleményformálásról vagy irányított fogyasztási magatartás kikényszerítéséről (Dawn \& Collins, 2018).

A marxi „óriási árugyüjtemény” (Marx, 1955) helyébe lépő „óriási spektákulumgyüjtemény" (Debord, 2006) debordi valósága az, amely az értelmezés keretéül szolgál. Ezzel nem egyeztethetö össze a „tömeges képterjesztési technológia kitermelte látásmóddal azonos" (Debord, 2006) értelmezés.

„A spektákulum a létezö rend önmagáról szóló, végeérhetetlen beszéde, öntömjénezö monológja. A hatalom önarcképe, egy olyan korban, amikor e hatalom totális uralma a létezés minden feltételére kiterjed." (Debord 2006). A szerzők végül megerösítik azt az álláspontjukat, miszerint az a folyamat, amelynek eredményeképpen az amerikai társadalmi diskurzusban elfogadottá válik az állami 
erőszak szükségessége és a militarizáció fetisizálása, nem helyes irány. A társadalom ebben a helyzetében - beleegyezésével és a fogyasztással - a neoliberális elit által foglyul ejtett állam bűnrészesévé válik (Collins \& Dawn, 2019).

E kritikus szemléletű megközelítésnek a kéthavonta megjelenő Critical Sociology címü folyóirat ad otthont, amelyet az 1968-as radikális mozgalmakat követően, 1969-ben The Insurgent Sociologist néven hoztak létre az Amerikai Szociológiai Társaság radikális szárnyát képviselő kutatók. A folyóirat szellemi hagyományait a szerzők megközelítése hủen tükrözi (Ruttan, 2006).

\section{Felhasznált irodalom}

Collins, V. E. \& Dawn, L. R. (2019). The Violence of Neoliberalism, Crime, Harm and Inequality. 1st edition. Routledge. https://doi.org/10.4324/9780429505768-1

Dawn, L. R. \& Collins, E. V. (2018). Consent and Consumption of Spectacle Power and Violence. Eastern Kentucky University

Debord, G. (2006). A spektákulum társadalma. Balassi Kiadó.

Eisenhower, D. D. (1961). „Military Industrial Complex”. Youtube.

Marx, K. (1955). A töke. Köt. I. 3. Szikra Kiadó

Mullen, A. (2010). „Twenty years on: the second-order prediction of the Herman-Chomsky Propaganda Model”. Media, Culture \& Society, 32(4), 673-690. https://doi. org/10.1177/0163443710367714

Pogátsa, Z. (2017). „Mi a neoliberalizmus? 2. Rész: A neoliberalizmus a jobboldal megerösödéséhez vezet". https://ujegyenloseg.hu/mi-a-neoliberalizmus-2-resz-a-neoliberalizmus-a-szelsojobb-megerosodesehez-vezet/

Rothe, D. L. \& Collins, E. V. (2018). „Consent and Consumption of Spectacle Power and Violence". Critical Sociology, 44(1), 15-28. https://doi.org/10.1177/0896920515621119

Ruttan, V. W. (2006). Is War Necessary for Economic Growth? Military Procurement and Technology Development. Oxford University Press. https://doi.org/10.1093/0195188047.003.0008

\section{Nagy Ivett \\ Csalás okiratokkal: biztosítható-e a személyek azonosíthatósága a huszonegyedik században?}

\section{Document fraud: can the identity of individuals be ensured in the twenty-first century?}

A szerző írásában az okiratokkal történő csalásokat vizsgálja. Célja az okiratokkal történő csalás fogalmának meghatározása és egyes elkövetési magatartások 
bemutatása. Példáit saját kutatásaira és az interneten elérhető információkra alapítja. Ugyanakkor jelzi, hogy e tárgykörben nehéz hozzájutni szakirodalmi elemzésekhez.

A tanulmány kiemeli, hogy egy olyan bűncselekmény-kategóriát vizsgál, ami gyakran összefügg más büncselekményekkel, köztük olyan súlyos deliktumokkal, mint az emberkereskedelem vagy a terrorizmus. A történeti kitekintésben szó esik arról is, hogy a késő középkorban megjelent annak az igénye, hogy adott személyt azonosítani tudjunk, felmerült a kérdés, hogy „ki vagy te?”, mi alapján állapíthatók meg az ismeretlen személy adatai. Napjainkban az okmányoknak (például útlevél, vezetői engedély, személyi igazolvány) meghatározó szerepük van az azonosításban. A személyi adatok hitelességének különösen nagy jelentősége lehet az élet olyan területein, mint a munkahelyválasztás vagy bizonyos szolgáltatásokhoz való hozzáférés.

Az elmúlt években a személyazonosság meghamisítása, valamint az okiratokkal történő csalások mindegyike kiemelt hangsúlyt kapott. Ezt bizonyítja az is, hogy az Europol által elemzett adatok szerint az okiratokkal történő csalás a szervezett bünözés egyik fontos mozgatórugója. Néhány országban az okiratokkal történő csalások a leghangsúlyosabbak, tekintettel arra, hogy ezek jelentik az egyik legnagyobb fenyegetést a közbiztonságra. A szerző statisztikai adatokkal is reprezentálja a helyzet súlyosságát. A Frontex által kiadott egyik számszerü értékelés szerint 2017 és 2018 között körülbelül 8100 hamis vagy hamisított dokumentum került a hatóságok által azonosításra, valamint 6700 olyan személy lépett be Európába, akik ezeket a hamis vagy hamisított dokumentumokat felhasználták. Említésre kerülnek továbbá a hamis vagy hamisított dokumentumok egyes típusai is. A tanulmány a hamisítások öt típusát különbözteti meg, amelyek ismeretében felderíthető a hamisítási folyamat. A szerző jogosan teszi fel a kérdést, hogy az elmúlt években megjelent úgynevezett e-dokumentumok vagy a biometrikus okmányok jelentenek-e akadályokat a hamisítások terjedésében. A szerző egyértelművé teszi, hogy a hamisítók alkalmazkodtak a változáshoz. Ezt támasztja alá például az is, hogy 2018-ban a hamis vagy hamisított útlevelek 43\%-a volt e-dokumentum.

A bűnözők célja legtöbb esetben az, hogy személyük rejtve maradjon, és így elkerüljék a leleplezést. Egyes elkövetők az internetet is kihasználják, ahol már különbözö felületeken lehetőség van hamis vagy hamisított dokumentumok vásárlására. Ebben az esetben a hamisító személyének azonosítása sokkal hosszabb időt vesz igénybe, hiszen maga a vásárló sincs tisztában azzal, hogy pontosan kitől szerzi meg a kívánt dokumentumot. Egy 2017-es tanulmány foglalkozott azzal, hogy milyen felületeken kínálnak és árulnak hamis vagy hamisított dokumentumokat. A szerző ezekről részletesen beszámol. A következtetés az, hogy 
az internet útján megvalósuló hamisítások merőben különböznek azoktól az elkövetési módszerektől, amelyek személyes kapcsolatokra épülnek. A nyomozó hatóságoknak nagy kihívást jelent, hogyan tudják figyelemmel kísérni az egyes weboldalakat, és miként vonhatnak le következtetéseket a hamisításokra. Ezekben az esetekben leginkább digitális információk állnak a nyomozó hatóságok rendelkezésére. A nyomozást segíti viszont az, hogy a weboldalak hasonlók egymáshoz, és jellemzően ugyanazon személy vagy szervezet müködteti azokat. A szerző megállapítja, hogy a személyazonosság megállapítása a 21. században sem tartozik a könnyen megoldható feladatok sorába, a hatóságoknak számos kihívással kell megbirkózni. A fenyegetések mértéke és súlyossága a jövőben sem fog csökkenni. Végezetül a szerző úgy fogalmaz, hogy a személyazonosság megállapításának biztonságosabbá tételét úgy tudjuk elérni, ha előmozdítjuk és megerősítjük valamennyi résztvevő fél, így a kriminológusok, a kriminalisztika területén kutatók, a bünüldöző hatóságok és a biztonsági okmányok gyártásával foglalkozó iparágak együttmüködését.

\section{Felhasznált irodalom}

Baechler, S. (2020). Document Fraud: Will Your Identity Be Secure in the Twenty-first Century? European Journal on Criminal Policy and Research 26(3), 379-398. https://doi.org/10.1007/ s10610-020-09441-8

\section{Fejes Attila}

\section{A digitális adatok és a biztonság}

\section{Digital data and security}

A 21. század első évtizedeire elértük azt, hogy mindennapi életünk egyik legföbb, legnagyobb hatással bíró fogalma a digitális adat lett. Létünk minden egyes napja bájtok millióival van kikövezve: ébredésünk után mobilunkért nyúlunk, e-maileket, üzeneteket válaszolunk meg, csetelünk, kommentelünk, átfutjuk a híreket, mindezekkel digitális nyomot hagyva magunk után, amelyeket szorgos cookie-k gyüjtenek, hogy a következő nap még aktuálisabb, testre szabottabb tartalmakkal - és hirdetésekkel - érhessenek el minket. Amint kilépünk házunk kapuján és elérünk célunkhoz, tízes nagyságrendben rögzítik videokamerák a mozgásunk útvonalát, nem beszélve mobiltelefonjaink cellainformációiról, bankkártyahasználati vagy a világhálón történő 
áru- és szolgáltatásvásárlási szokásainkról stb. Munkánk során sok esetben adatot hozunk létre, dolgozunk fel vagy egyszerúen felhasználjuk azokat a produktumunk elöállításához. Hazatérve otthonunkba szintén folytatódik életünk bájtokban történő leképezése és még éjszaka is algoritmusok kutatják például lehetséges emberi kapcsolatainkat a közösségi média felületein. A modern technológiával lehetővé vált többféle fizikai és viselkedésbeli jellemzőink leképezése: a biometrikus adataink rögzítése és felhasználása beazonosításunkra, ezzel a személyes adataink köre jelentősen kibővült. A szerző cikkében a személyünkhöz köthető adataink keletkezését, tárolását, felhasználását és a prediktív rendészet hatékonyságát vizsgálja a jogi szabályozó eszközök, az adatbiztonság, továbbá a rendészet dimenzióiban.

Az első fejezet rámutat az adatok gyüjtésének, elemzésének jelentőségére a rendészeten belül. Ez megvalósul a bünügyek aktáinak teljes körü elemzésével, a lehetséges gyanúsítottak adatainak gyüjtésével, rögzítésével. Kiemeli a biometrikus személyazonosítás jelentőségét a büntetőeljárásban, a különböző biometrikus profilok felépítésének hasznosságát. Az egyedi személyazonosításra alkalmas biometrikus modellek jelentősége két módon ragadható meg: egyrészt a büncselekmény helyszínén rögzített (például ujjnyomat, DNS) vagy egyéb módon a hatóság birtokába jutott minta (arc-, hang-, biometrikus modell stb.) és a gyanúsított mintáinak összehasonlítása a személyazonosság valószínüségének meghatározása céljából. Másrészt a biometrikus minta alkalmas big data technológiai környezetben nagy rekordszámú adatbázisokban történő feldolgozásra, keresésre. A szerző rávilágít arra, hogy ez utóbbi személyiségi jogi és adatbiztonsági problémákat is felvet. A személyes adatok biztonsága, a magánélethez való jog, az önrendelkezés joga elsőrendü, ugyanakkor az egyedi azonosításra alkalmas adatok gyüjtése mindezeket sértheti. Az automatizált adatfeldolgozással megvalósulhat az egyén jogainak nagyobb fokú korlátozása, hiszen életének, tevékenységének monitorozása sokkal széleskörübben valósulhat meg, mint korábban, lásd kilencvenes évek. Albrecht cikkében többször utal rá, hogy az adatok megörzésének időbeli korlátozása kiemelten fontos, hiszen minél nagyobb időtávon valósul meg a tárolás, annál pontosabban térképezhető fel az egyén mindennapi élete. A szerző a nemzeti utasadat információs rendszer példáján keresztül érzékelteti, hogy a személyes adatok gyüjtése és korlátozása kiemelten fontos, ugyanakkor az országok közötti információcsere tủpontos szabályozása elengedhetetlen.

A második fejezet a prediktív rendészet fogalomkörén belül vizsgálja az adatbiztonságot és a különböző rendőrségi stratégiákat. A szerző megállapítása szerint elmozdulás észlelhető egy adatközpontú stratégia felé, amelyet példáz a közösségi média szinte mindenre kiterjedő adatgyüjtése és az adatbányászati 
technológiák fejlettebbé válása. A prediktív rendészet itt már létező technológiát jelöl, amelynek alkalmazásával előre jelezhető egyes büncselekmények bekövetkezésének valószínűsége, jellemzői, valószínűsíthető elkövetői. A cikk írója adatolja a bünügyi statisztikában a betörések számának változását, és felmutat egy megoldást a bünesetek csökkentése céljára: a prediktív rendészet eszköztárával olyan szoftver létrehozása, mellyel jósolható, így a lépések megtételét követően csökkenthető a büncselekmények tulajdonságai, száma. Albrecht szerint módszertanilag megalapozott az a kísérlet, amely a nagy kockázatú személyek azonosításán alapul standardizált előrejelző eszközök segítségével. A prediktív rendészet kiindulópontja a New York-i rendőrségen bevezetett CompStat rendszer, amely a bünügyi statisztikák célzott elemzésén alapul. Megállapítja, hogy a fö fókusz inkább a ritkán elöforduló, mint a tömeges büncselekményeken van, amelyek elemzéséhez nincs szükség kifinomult matematikai módszerekre. Ugyanakkor az egyén kockázatértékelésével megkísérelhető a nagy kockázatú személyek azonosítása standardizált előrejelző eszközök alkalmazásával. A cikkben utalás történik a terrorellenes harcra, amelyen belül a potenciális gyanúsítottak kockázatkezelési programokat alkalmazva kerülnek a rendőrség vagy a nemzetbiztonsági szolgálatok látókörébe. A prediktív rendészet és a nemzetbiztonsági szolgálatok kapcsolata egészen sajátos, ugyanis míg a rendőrség - tágabb értelemben a rendészet - nem olyan régen alkalmaz prediktív eszközrendszert, addig a titkosszolgálatok alapvető módszerei közé tartozik a lehetséges elkövetői vagy ellenérdekelt célcsoportok kockázatelemzés módszerével történő megfigyelése. Jelen tanulmány is kapcsolatot hoz létre a rendőrség és az egyéb szolgálatok prediktív módszerei között, s mindezeket jogszabályi, államközi egyezmények nevesítésével is bemutatja. A szerző részletesen bemutat egy tipikus folyamatot: első lépésben kockázatértékelés és osztályozás történik, majd a minősítés alapján különleges rendőri aktát nyitnak a célcsoportnak, célszemélynek. Ezt követően a kockázatosnak minősített személyeket tájékoztatják és figyelmeztetik, hogy miért vannak szisztematikus és állandó megfigyelés alatt és milyen feltételek mentén szünhet meg a megfigyelésük.

Habár a prediktív rendészet eredetileg a betörések megakadályozását tüzte ki célul, a későbbiekben a szemlélet megváltozott, a prediktív rendészeten ma már szélesebb körü tevékenységet értenek, köszönhetően a közvélemény és a politikai szereplők megváltozott igényeinek is. A kiindulópont az volt, hogy a bünözőket is szokások jellemzik, így hajlamosak megismételni a korábban elkövetett büncselekménytípusokat. Habár a specializációval kapcsolatos feltételezések nem minden esetben igazak általánosan, de egyes büncselekménytípusoknál jól müködnek a kockázatértékelési rendszerek. Ugyanakkor a terrorizmus elleni harcban az elörejelzések kevésbé hatékonyak a megjósolható események ritkaságából adódóan. 
Mivel célzottan és széleskörüen végrehajtott készletező adatgyüjtésről, adatmegőrzésről és szürő-kutató tevékenységről beszélünk, fontos megemlíteni az adatbiztonságot és a személyes adatokhoz, a magánélethez füződő jogok védelmét. A szerző EU jogforrásokkal és nemzetközi jogi normákkal alátámasztva tárgyalja, hogy a büncselekmények megelőzése és felderítése céljából végrehajtott adatgyüjtés szembeállítható a magánélethez való joggal. A célhoz kötöttség elve a korábban említett prediktív rendészet és kockázatelemzés, -kezelés fogalomkörében másképp értelmezendő. Míg klasszikus megközelítésben a célhoz kötöttség azt jelenti, hogy csak meghatározott, egyértelmü és jogszerü célból lehet adatgyüjtést megvalósítani, a készletező adatgyüjtés és adatmegörzés során nem határozható meg pontosan az elérendő cél - leszámítva a büncselekmény megelőzését. Emiatt például az Európai Bíróság kimondta a 2006/24 EK semmisségét és részletesen indokolta döntését a hívásforgalmi adatbázisok felhasználásának jogi aggályaival. További példát mutat be a szerző a biometrikus jellemzők (például DNS, ujjnyomat) rögzítése, tárolása és felhasználása jogi aggályairól. Kétségtelen a titkos információgyüjtés létjogosultsága, ugyanakkor kérdéses milyen egyensúly érhető el a személyiségi jogokkal összevetve. Szerző rámutat arra, hogy kiemelten fontos az egyén azonosítóinak adatbázisba történő felvételének indoklása, az adatmegőrzés szükségességének alátámasztása. Fontos a metaadatok kezeléséről beszélni, hiszen napjaink digitális világában mindezek a korábbiakhoz képest szélesebb körben keletkeznek és pontosabb betekintést engednek az egyén magánéletébe, szokásaiba, társadalmi életébe. A szerző nem tárgyalja, de felvetődik a titkos információgyüjtés engedélyezésének újraszabályozása, hiszen a bírói vagy miniszteri hatáskörbe utalt eszközök (például telefonlehallgatás) alkalmazásánál egyes esetekben a csak belső engedélyezésű (az egyes szolgálatok vezetői által jóváhagyható) módszerek nagyobb mértékben sértik meg a magánélethez füződő jogainkat, mivel alaposabban térképezhető fel életünk, napi tevékenységünk, kapcsolataink, preferenciáink stb. A tárgykörben fontos kiemelni az adatmegőrzés időtartamát. Kétségtelenül fontos, hogy adott esetben évekre visszamenőleg is elemezhetők legyen hívásforgalmi adatok, azonban e témában is kiemelten fontos az egyensúly megteremtése a bünüldözés és a magánélethez füződő jogok között.

A tanulmány záró fejezete a prediktív rendészet eredményeit tárgyalja. A módszertan alkalmazásával a cél a büncselekmények számának csökkentése a bünmegelőzés eszközrendszerével. Németországban a kockázatkezelési programok és a prediktív rendészet eredményeinek kutatása eddig elszigetelt esetekben valósult meg. A programban lefedett területeken a büncselekmények száma nem csökkent, azonban az adatok teljeskörüen nem álltak a kutatók rendelkezésére. Egy, a prediktív rendészet értékelésére szolgáló projekt Chicagoban vitákhoz 
vezetett az összefüggések létrehozása miatt. Az eredmény nem volt meglepő: egy gyilkosság lehetséges áldozatainak listáján szereplő személyeket nagyobb valószínüséggel tartóztatták le lőfegyverrel kapcsolatos büncselekmények miatt. A szerző zárásul, több konkrét példát említve felveti a kérdést, hogy a prediktív rendészet eszköztára milyen hatékonysággal csökkenti a bünözést és milyen valószínüséggel előzhetők meg alkalmazásával a büncselekmények.

\section{Felhasznált irodalom}

Hans-Jörg A. (2020). Data, Data Banks and Security. European Journal for Security Research, 5, 5-23. https://doi.org/10.1007/s41125-019-00062-9

\section{Rompos Éva Amikor algoritmus és mesterséges intelligencia (is) hoz döntést büntetőügyekben: a hatékony jogorvoslat keresése}

\section{When algorithm and artificial intelligence (also) make decisions in criminal matters: finding an effective remedy}

Napjainkban elkerülhetetlenné válik a mesterségesintelligencia-rendszerekkel (artificial intelligence, rövidítve AI) való interakció, ezzel átalakítva emberi tevékenységeink nagy részét: már ma is algoritmikus társadalomban élünk (Balkin), ahol jelenleg paradigmaváltás zajlik ezen rendszerek alkalmazásában. A hagyományos számítógép által támogatott (humán) szakértői rendszerek (ismeretanyaguk, logikai következtetéseik) beépítésre vagy helyettesítésre kerülnek a gépi tanuláson alapuló, összetett, folyton változó és hatalmas adatmennyiséget (big data) használó mesterséges intelligencia által. A büntetöjog sem ússza meg ezt a változást: az eltérő igazságszolgáltatási rendszerek szereplői is használják már az emberi döntéseket igénylö folyamataik támogatására az A/AI rendszereket. A cikk az algoritmusokat $(\mathrm{A})^{1}$ és AI-t használó prediktív rendszerek hatását vizsgálja az alapvető emberi jogoknak és a tisztességes eljárás alapelvének a betartása szempontjából, illetve elemzi a hatékony jogorvoslat lehetőségét e technológiák által támogatott büntetőeljárásokban.

1 Algoritmuson (rövidítve: A), más szóval eljáráson olyan, előre meghatározott lépésekből álló módszert, utasítássorozatot értünk, mely egy adott probléma megoldására alkalmas. 
A szerzők szerint ezek a rendszerek olyan fekete dobozként müködnek, ahol a bemenet és a kimenet jól megfigyelhetö, de a belső folyamatok homályban maradnak, még akár a programozók számára is. Müködésük alaphelyzete a következő: a rendszer referenciacsoportokba osztályozza az egyéneket (például alacsony, közepes, magas visszaesési ráta; alacsony, közepes, magas bünügyi kockázat a földrajzi helynek megfelelően stb.) majd az algoritmizált döntési folyamatban ezek alapján javaslatot tesz arra, hogy egy adott egyén hogyan kezelendő. A funkció olyan, mint egy jóslás, azonban tekintettel az előzményként feldolgozott adat és információ mennyiségére (és minőségére), ez a jóslás statisztikailag rendkívül pontos. Konvencionális, a prediktív rendészet eszközeit felhasználó rendszereket mind Európában, mind az Egyesült Államokban alkalmaznak a potenciális elkövetők, események azonosítására vagy egyéni kockázatelemzésre. Az A/AI rendszerek bemeneti adatainak biztosítása, a feldolgozás eredményének interpretálása, a beavatkozások hatékonyságának bizonyítása és a hatékony jogorvoslat lehetősége sok kérdést vet föl. Rendszerek, melyek müködését vizsgálták:

- PredPol - Los Angeles (URL1): a büncselekmény típusa, az elkövetés helye és ideje alapján, webes felületen, Google Maps segítségével történik az elörejelzés azokról a területekről, ahol egy adott időpontban megnő valamely kriminális cselekmény valószínüsége. Ez a fajta elemzés azonban megnöveli (a területi) diszkrimináció lehetőségét.

- KeyCrime delia ${ }^{\circledR}$ - Milánó (URL2; URL3): rablások, szexuális büncselekmények adatainak elemzésével keresi a kapcsolatokat, és előre jelzi az öszszefüggő büncselekmény-sorozat bekövetkezését.

- COMPAS - Kalifornia: statikus és dinamikus változók bevitelével, az alany által kitöltött kérdöív alapján egy kockázati pontszám segítségével becsli meg a visszaesés, az erőszakos büncselekmény újbóli elkövetésének lehetőségét, ezzel segítve a döntéshozót az előzetes szabadon bocsátásban vagy a felfüggesztett ítéletek kiszabásában.

- PSA - USA: tárgyalás előtti szakaszban azt a kockázatot becsli meg, hogy a vádlott nem jelenik meg az idézésre, illetve mekkora a bünismétlés kockázata. A COMPAS-t ért kritikák alapján nyilvánossá tették a rendszer müködési elvét, azt a kilenc faktort, amivel a program számol.

A szerzők szerint a részben vagy teljesen automatizált kockázatelemzés, illetve döntéshozatal - a fenti példák alapján is - nagyban veszélyezteti:

- az egyénről összegyüjtött információ elérésének jogát, lehetőségét;

- a tisztességes eljáráshoz való jogot; 
- a rendelkezésére álló hatékony jogorvoslás lehetőségét;

- aláássa az ártatlanság vélelmét;

- kizárja a hallgatás (önvádolás megtagadásának) jogát.

Véleményük szerint minél előbb ki kell dolgozni olyan technikai és jogi garanciákat, melyek képesek megelőzni, hogy az igazságszolgáltatásban alkalmazott A/AI rendszerek alapvető emberi jogokat sértsenek. Müködésük megértéséhez biztosítani kell a forráskód megadását ${ }^{2}$. Ha ez a szellemi tulajdon védelme vagy ipari, kereskedelmi okok miatt nem lehetséges, akkor a müködési elvet közérthetően ismertetni kell ${ }^{3,4}$.

Az automatikus rendszerek téves következtetéseket is levonhatnak, hiszen egy kimutatható matematikai összefüggés egyáltalán nem jelenti az ok-okozati öszszefüggést!

A müködés alapjául szolgáló adatbázis megfelelősége, hibátlansága nagyban befolyásolja a későbbi hibákat: nem mindegy, hogy milyen alapadatok szolgáltak az AI betanításához. Az utcai bünözés adatai nem szolgálhatnak alapul a fehérgalléros büncselekmények elemzésénél.

Kérdéses az érzékeny adatok eltávolítása (faji, etnikai hovatartozás, politikai vélemény, vallási nézetek, egészségi állapot, szexuális beállítottság stb.); a mesterséges intelligencia ezek nélkül is levezethet aggályos következtetéseket (vásárlási adatok elemzéséből személyhez köthetö terhességi jövendölés esete (URL4).

\section{Javaslataik:}

- a rendszereket müködtetőknek tisztában kell lenniük azok képességeivel és határaival;

- tudjanak ezen rendszerekkel megfelelően kommunikálni;

2 Szakértői információk alapján a forráskód megadása sem elegendő. Nagyon sok AI algoritmus általános elveken alapul, és a müködés helyességének megítélése az algoritmus alapján nem lehetséges (hisz az algoritmus alapvetően jó). Ahhoz, hogy megállapító legyen, hogy egy AI rendszer „korrekt” (vagy legalábbis elfogadható) minőségü döntéseket hoz, elengedhetetlen a tanító adatbázis és a tanítás során alkalmazott paraméterek ismerete is. Például, ha egy arcfelismerö rendszert csak fekete vagy latin elkövetök adataival tanítják vagy akárcsak elbillen az arány a fehér, fekete, latin stb. képek között, az AI döntési eredményei is torzak lesznek.

3 Az AI nem kódolt algoritmus alapján hozza meg a döntéseit, hanem tanul. A tanító mintában „,ismeri fel" a szabályszerúségeket, amelyeket leképez a belső logikájában. Ebbe a logikába tudatosan és véletlenül is lehet vakfoltokat tanítani, azaz olyan döntési területeket (bemeneti paraméter együttállásokat), amelyekre az AI nem tud megfelelöen válaszolni. Ezért az AI megértésében a tanító adatok konzisztenciájának, teljességének elemzése sokkal nagyobb feladat, mint az algoritmus megértése.

4 Ez persze további kérdéseket vet föl: a klasszikus IT rendszerek hacker támadásakor szoftver hibákat kihasználva jutnak be a támadók, és férnek hozzá információkhoz vagy manipulálják azokat. Az AI támadások során a támadó az AI megoldás algoritmusában vagy a tanítás módjában rejlő egyedi sajátosságokat megismerve olyan adatot szolgáltat a rendszernek, amelyre az hibás döntést hoz. 
- legyenek beépített humán értékelési, ellenőrzési szempontok, lehetőségek, azaz szünjön meg az adat mindenekfelettisége, helyét vegye át az informált bizalom;

- az eredmények reprodukálhatók legyenek;

- ellenőrizni kell a rendszer pontosságát (eltérő bemenő adatok esetén milyen mértékben szolgáltatnak eltérő eredményt);

- robosztusságát (kezelésében nem jártas személy közremüködésével milyen eredmény születik);

- üzembe állítás előtt (ex ante) hatósági felügyelet melletti tanúsítás,

- valamint már müködö rendszerrel való összevetés, azaz validálás szükséges;

- ezt az úgynevezett érvényesítési folyamatot dokumentáltan,

- a folyamat összes résztvevőjének (bírák, ügyészek, rendészeti szervek, ügyvédek) felügyelete, részvétele mellett, időszakosan megismételve kell végrehajtani. ${ }^{5}$

Az A/AI rendszerek szabályozatlan használata csökkenti az alapvető jogok hatékony gyakorlását, ezért a szerzők szerint nem elegendő a fentieket nemzeti hatáskörben biztosítani, szükség van a közösségi jog támogatására is.

Azt azonban ki kell, ki lehet jelenteni, hogy e rendszerek használata nagy lehetőség arra, hogy büntetöügyekben teljesen átalakuljon a jelenlegi döntéshozatali rendszer (URL6).

\section{Felhasznált irodalom}

Contissa, G. \& Lasagni, G. (2020). When it is (also) Algorithms and AI that decide on Criminal Matters. In Search of an Effective Remedy. European Journal of Crime, Criminal Law and Criminal Justice, 28(3), 280-304. https://doi.org/10.1163/15718174-bja10014

\section{A cikkben található online hivatkozások}

URL1: The Predictive Policing Company. https://www.predpol.com/

URL2: Delia. https://www.keycrime.com/delia

5 A javaslat kísértetiesen hasonlít a más területeken már müködő rendszerhez: „Az akkreditálás annak hivatalos elismerése, hogy egy szervezet, természetes személy alkalmas bizonyos megfelelöségértékelési tevékenységek (...) elvégzésére. Az akkreditálás célja az egységes európai elvekre épülö akkreditálási rendszerekben elismerést nyert szervezetek iránti bizalom növelése, a vizsgálati, tanúsítási és ellenörzési tevékenység megbizhatóságának emelése, a vizsgálati eredmények és tanúsitványok kölcsönös elfogadásának elösegitése, megteremtve ez által az ismételt vizsgálatok kiküszöbölését és a kereskedelem müszaki akadályainak elháritását." (URL5). 
URL3: KeyCrime - Predictive Crime Analysis Software. https://www.youtube.com/watch?v=6jOXJU4IYdw

URL4: Luciano Floridi: The Fourth Information Revolution and its Ethical and Policy Implications. https://www.youtube.com/watch?app=desktop\&v=iMphPZKLje8\&ab_channel=IIEA URL5: Mi az akkreditálás? https://www.nah.gov.hu/mi-az-akkreditalas

URL6: A biróságok és a technológia. https://birosag.hu/birosagiszemle/2020/1/_birosagok-es-technologia

\section{Kalmár Ádám}

\section{A rendőrség militarizálása: a kanadai és az Egyesült Államokban múködő paramilitáris egységek összehasonlítása}

\section{Police militarization: a comparison of paramilitary units operating in Canada and the United States}

Kutatók és civil jogvédők az elmúlt évtizedekben folyamatosan nyomon követték azt a mindenhol megfigyelhető folyamatot, hogy a rendőrségek katonai jelleget öltő egységeinek száma növekszik, és azok felépítése, felszerelése, valamint tevékenységük módszertana is militarizálódást mutat. A szerzők - Kevin Cyr a Kanadai Királyi Lovasrendőrség tisztje, Rosemary Ricciardelli a Kanadai Memorial Egyetem szociológia professzora és Dale Spencer a Carleton Egyetem Jogtudományi Tanszékének docense - példákon keresztül vizsgálják meg Kanada és az Egyesült Államok rendőrsége katonai jellegü egységeinek növekvő számát, és e folyamat közbeszédben megjelenő kritikáját.

A kanadai és az amerikai különleges rendöri egységekkel szembeni elvárások és a feladataik is közel azonosak veszélyhelyzetekben, terrorizmus elleni akciókban vagy túszejtések esetén. Amerikában mégis jóval hangosabbak a kritikus hangok az ilyen egységek (továbbiakban SWAT egységek) felszerelése, taktikai megoldásai, képzése és esetenként elhibázott akciói miatt, mint az ugyanolyan egységekkel rendelkező Kanadában. A szerzők a két ország közvéleményének szembeállítását az USA-ban, Ferguson városában 2014-ben lezajlott zavargások példájával mutatják be, ahol éles tiltakozást váltott ki, hogy nem emeltek vádat egy fekete tinédzserre halálos lövéseket leadó rendör ellen. Ezt követően a médiát tematizálta a városba vezényelt, nagyszámú terepszínú egyenruhát viselő, katonai szintü felszereléssel rendelkező, páncélozott jármüvekkel járőröző rendőri egységek tevékenysége. Azt a mechanizmust érte a legtöbb vád, mely alapján a rendőrség SWAT egységei egyre több feleslegessé vált katonai felszerelést vesznek át használatra. Egy év múlva egy külön munkacsoportot 
állítottak fel, melynek feladata annak értékelése volt, hogy hogyan lehet gátat vetni a rendőrség katonai felszerelés beszerzéseinek. Kanadában ezzel szemben a Ferguson-beli zavargások idején - és azóta is - sokkal enyhébb kritikák fogalmazódtak meg, elsősorban a növekvő számú katonai célú rendészeti gépjármü és katonai egyenruhák megjelenése miatt. Ezeknek nem lett politikai hatása, mert alapvetően nem nőtt a paramilitáris rendőri egységek bevetéseinek száma, sőt egy részüket a napi járőrözési rendszerben is alkalmazták.

A szerzők alapvető különbségeket találtak a két ország rendőrségének katonai jellegü egységei között a katonai felszereléshez való hozzájutás és a szervezeti felépítés terén is. Megállapítják, hogy az USA-ban több állami program is segíti a rendőri egységeket abban, hogy ingyen jussanak hozzá felesleges katonai eszközökhöz (az aknával történő rajtaütés ellen védett páncélozott harcjármüveket is beleértve), lebontva ezzel a költségek okozta akadályokat. Kanadában ellenben ezen eszközöket a piacról kell beszerezni költségvetésük terhére. A költségmentes beszerzés az USÁ-ban a paramilitáris rendőri egységek számát és méretét is befolyásolta. Ezért az USA gyakorlatában nagyszámú, de kisméretü SWAT egység jött létre, amelyek rendőrei sok esetben „csatolt munkakörben” végzik különleges feladataikat a saját szükebb illetékességi területükön. Kanadában a SWAT egységek kisebb számban, de nagyobb állománnyal alakultak meg, a beosztottak kizárólag a speciális rendőri műveletekben kerülnek bevetésre, de nagyobb regionális illetékességgel.

A kutatók föként amerikai példákkal illusztrálják, hogy a drágán fenntartható paramilitáris rendőri egységekhez tartozó „elit” állomány kiválasztásához megfelelő számú jelentkező, felkészítésükhöz pedig magas minőségü, legalább a szolgálati idejük 25\%-át elérö képzés kell, melynek okán a kisebb rendőri egységek részére kihívás SWAT egységet fenntartani, bár az Egyesült Államokban ez mégsem példa nélküli. Amikor egy meglepetésszerü házkutatásnál a megfelelö felderítés hiánya miatt emberi tragédia történik, vagy egy erőszakos cselekményt követően túl sok kis SWAT egység érkezik a helyszínre, akkor több esetben tapasztalható volt, hogy az összehangolatlan vezetés a müveletek sikerét negatívan befolyásolja annak ellenére, hogy az USA-ban létezik nemzeti szinten egységes bevetési metodika. Kanadában ezzel szemben a katonai jellegü különleges rendőri egységek vezetőinek egységes müveleti módszertant dolgoztak ki, mely az amerikai legjobb gyakorlatokon alapul, így élvezhetik a nemzeti szinten összehangolt felkészítés előnyeit.

A kutatók részéről vizsgálat tárgyát képezte a különleges rendőri egységek feladatainak több mint háromnegyedét kitevő bejelentés nélküli házkutatások végrehajtásának jogszerüsége is. Amerikában alapvető jogi kritérium, hogy a magánlakásokba történő behatolásokat előzetesen egy bíró engedélyezze, azonban 
létezik jogi megoldás ennek elkerülésére, amikor házkutatás végrehajtása érdekében felszólítják a lakót, hogy az ajtót nyissa ki, de - tekintve, hogy a késedelem a bizonyítékok megsemmisítésének veszélyével járhat vagy a bevetésre kerülő rendörök biztonságát sértheti - azt azonnal be is törik és behatolnak. Ilyenkor a bíróságok megvizsgálják, hogy a rendőrség felszólítás nélküli behatolása jogszerü volt-e annak fényében, hogy a keresett bizonyítékokat megtalálták-e. Ezzel ellentétben Kanadában a bíró nem engedélyez figyelmeztetés nélküli behatolást magánlakásba, ez a rendőrtiszt döntése. A panaszt elbíráló bíróság azonban azt vizsgálja, hogy az erőszakos behatolás előtt az eljáró SWAT egység hagyott-e elegendő időt a bejárat ajtó kinyitására. Az Egyesült Államokban például az Amerikai Civil Polgári Jogi Szövetség (ACLU) véleménye szerint a házkutatás érdekében figyelmeztetés nélküli rendőri behatolások bonyolult bírói engedélyezési eljárásai ellenére a bíróságok nem nyújtanak megfelelő védelmet a felfegyverzett, agresszív taktikai megoldásokat alkalmazó rendőri egységek ellen.

A kutatók a tanulmányban felteszik a kérdést, hogy szükséges-e az USA-ban a katonai típusú felszerelés és eszközök megszerzésének szigorítása, elsősorban azon rendőri szervek esetében, melyek a magas szintủ képzési feltételeknek nem felelnek meg. Adatokkal bizonyítják, hogy a SWAT egységek elterjedése nem feltétlenül hibás folyamat, inkább annak a szükséges következménye, hogy az amerikai rendvédelmi szervezetek tagjai sokszor kerülnek életveszélyes helyzetekbe. Azzal kell szembesülnünk, hogy a jelen növekvő biztonsági kihívásaira válaszul az egyszerü reguláris rendőri egységek munkájában megjelenő egyre nagyobb számú fenyegetések, egyre több erőszakos fegyveres bünelkövető ellen a szervezetek mértékadó válasza a militarizálódás felé vezet, melynek kezelése más-más megoldásokat szül. Hazánkban például kisszámú, de jól felszerelt és országos hatáskörü terrorelhárító egység müködik azonos vezetési és bevetési elveket és gyakorlatot követve, de ezen kívül valóban észrevehetö, hogy a rendőrség megyei főkapitányságai és például a vámhivatal is müködtet bevetési egységeket, ez azonban egyelöre nem szül kritikát a médiában és a közbeszédben.

A szerzők tételeivel egyet lehet érteni, azokat sok példával, számokkal alá is támasztották. Hiányérzete annyiban támad az olvasónak, hogy több kérdés is nyitva maradt, ilyen például, hogy a növekvő számú különleges egység hogyan befolyásolja a szervezeti kultúrát, vagy a félkatonai egységek terjedése, feladatik ellátásának összehangolása milyen hatással van a szervezetek felépítésére. A szerzők által felvetett kérdések a gyakorlat és az elmélet müvelőit egyaránt gondolkodásra késztethetik. (A hazai szakirodalom a rendészet militarizálódását nem a felszerelésben és a szakirányú rendészeti intézkedések végrehajtásában, hanem a szervezet belső müködésében, a végletes centralizációban, a katonai rendet másoló hierarchiában véli felfedezni.) 


\section{Felhasznált irodalom}

Ricciardelli, R., Cyr, K. \& Spencer, D. (2020). Militarization of police: a comparison of police paramilitary units in Canadian and the United States. International Journal of Police Science and Management, 22(2), 137-147. https://doi.org/10.1177/1461355719898204

\section{Urbán Ferenc}

\section{Szexuális kapcsolat a gyanúsított és a rendőrök között: meddig mehet el a rendőrség a prostitúció bizonyításában?}

\section{Sexual relationship between the suspect and police officers: how far can the police go in proving prostitution}

Noha a szexmunka és prostitúció az Egyesült Államok törvényei értelmében az egyik legkevésbé súlyos büncselekmény, mégis a prostituáltak elleni rendőri eljárások gyakran jogsértők. Alapvető probléma, hogy a prostitúció büntető törvénykönyv szerinti definíciója kevés támpontot ad a prostitúció tényállásának megállapításához, így sérül a jogbiztonság.

Ez a helyzet oda vezet, hogy a rendőrök olyan gyanúsítottakat is örizetbe vesznek, akik nem is valósították meg a büncselekményt.

Az USA-ban fedett rendörök szexuális kapcsolatot is létesítenek prostituáltakkal fizetségért cserébe, majd őrizetbe veszik a gyanúsítottat. A szerző álláspontja szerint ez a nyomozási módszer felveti annak a kérdését, hogy milyen mértékben sérül a gyanúsított tisztességes eljáráshoz való joga. Az USA alkotmánya biztosítja a jogot állampolgárainak a testi integritásukhoz. A prostitúció csapdával történő bizonyítása a gyanúsítottak testi autonómiájának a sérülését jelenti, ezért a szerző az ilyen jellegü fedett rendőri akciók betiltása mellett érvel. A továbbiakban a cikk szerzője definiálja a szexmunka mostanában alkalmazott fogalmát, ami tulajdonképpen tág cselekményi kört fog át. Ezek alapján a szexmunka szexuális szolgáltatás pénzért történő kínálatát jelenti, amelynek során a cselekmény - bár nem kizárólag, de kiterjedhet klienssel létesített direkt fizikai szexuális kapcsolatra. A szexmunka magában foglalhatja a prostitúciót, a sztrippelést, pornográfiát, telefonszexet, eszkort szolgáltatást és erotikus masszázst is. A szerző a cikkében a szexmunkás kifejezés helyett, amelyet a jelenlegi szexmunkások érdekeivel foglalkozó jogvédő szervezetek preferálnak, a prostituált kifejezést használja. Az USA szövetségi törvénye és 49 állam joga, valamint Nevada állam 4 megyéje tiltja a prostitúciót. Bár több bírósági ítélet is született, amely kimondja, hogy a fizikai kapcsolat nem szükséges a prostitúció 
bizonyítására, mégis a rendőrök egy része szexuális kapcsolatba lép a prostituáltakkal annak érdekében, hogy megfelelő bizonyítékot szerezzen. Több állam bírósága jogszerütlennek minősítette a rendőrök által végrehajtott ilyen fedett akciókat, de más esetben nem szabtak gátat a módszernek.

A rendőrök által prostituáltakkal megvalósított szexuális cselekmények értelmezése különösen nehéz feladat, mivel a cselekmény két felnőtt megállapodásán alapul. Ráadásul a rendőr és a prostituált közötti privát viszonyt feltételez. A prostituáltak egy része, azért, hogy leleplezze a fedett rendörnek vélt partnert, arra kérte kliensét, hogy ténylegesen megvalósítsanak bizonyos fajta szexuális cselekményt. A prostituáltak úgy hitték, hogy az igazi rendőrök visszautasítják ezt a fajta aktust, de ebben tévedtek, mert a különböző nyomozó szervek és egyes bíróságok jogszerünek fogadják el a felderítésnek ezt a módját is.

A szerző megállapítja, hogy az ilyen cselekedet a megfelelő rendőrségi utasítások hiánya miatt a gyanúsítottak méltányos eljáráshoz való jogát sérti.

Minnesota állam az Egyesült Államok kontra Cuervelo és Minnesota Állam kontra Burkland ügyekben olyan precedens értékü ítéleteket hozott, amellyel meghatározta a rendőrök és a gyanúsítottak közötti elfogadható szexuális viselkedés kritériumait. A Cuervelo ügyben a másodfok azt vizsgálta, hogy a rendőr és a gyanúsított közötti szexuális viszony elfogadható-e az eljárás jogszerüsége szempontjából. A Burkland ügy a Cuervelo féle eljárás egyik állítását használta fel indoklása során. A cikk szerzőjének megállapítása alapján ezek az érvek nem jelentenek elégséges alapot, ahhoz, hogy a prostituált és a rendőr közötti szexuális kapcsolat a jogszerüség szempontjából kerüljön megítélésre. A Cuervelo teszt és a Burklandi elemzés nem védi a prostituáltakat megfelelően, mert nem definiálja kellő alapossággal a jogszerüség összefüggésében a „nem megfelelő viszony" tartalmát. A Burkland ügyben a bíróság párhuzamot állított a drog ügyek nyomozása és a prostitúcióval kapcsolatos nyomozás között. A különbség a két ügytípus között abban rejlik, hogy amennyiben a rendőrök fedett eljárásban drogot vásárolnak, az csupán egy átlagos pénzügyi tranzakció, míg a szexuális szolgáltatás pénzért történő vásárlása során intim kapcsolat jön létre az eladó és a vevő között. A prostitúció fedett rendőri eljárásban történő felderítése során a rendőrök a gyanúsított testét használják fel arra, hogy bizonyítékot gyüjtsenek, kontrollálják a gyanúsított testét és igazolják bünösségét. Az ilyen eljárásban megvonják a gyanúsítottak jogát a szexuális aktusba történő beleegyezéstöl, mert a prostituáltak nem ismerik a kapcsolatfelvétel eredeti célját.

A gyanúsítottak és a fedett rendőrök közötti szexuális kapcsolatban az erőviszonyok sincsenek egyensúlyban, az egyértelmü beleegyezés hiánya a fedett eljárás során a nyomozókat arra is késztetheti, hogy visszaéljenek a helyzettel, mivel a fedett nyomozó a viszony egyedüli tanúja, az nélkülöz minden külső kontrollt. 
A cikk egyik legfontosabb megállapítása, hogy a prostitúció jelenlegi meghatározása jellemzően túl tág, mert nem szerepel benne a pénzért folytatott szexuális cselekmény fordulat. A jelenlegi törvényi tényállás szerint az is prostitúciónak minősül már, ha valaki csak pénzért beleegyezik a prostitúcióba, anélkül, hogy megvalósulna a szexuális cselekmény. Ez megkönnyíti a fedett nyomozó számára a csapdába ejtést. Az amerikai társadalom eldöntötte, hogy a prostitúció morálisan rossz és olyan jogszabályokat hozott, amelyek igyekeznek gátat szabni terjedésének. Nyilvánvaló, hogy a prostitúció fedett eljárásban történő leleplezése különleges problémaként jelentkezik a bünüldöző szervezeteknél és a bíróságokon. Felmerül annak a kérdése, hogy a nyomozók által elöállított csapdahelyzet nem tekinthetö-e felbujtásnak? A prostitúció büncselekményének jelenlegi meghatározása túl tág és igazságtalan, mivel a rendőrségnek már a szexuális cselekmény távoli kísérlete esetén is megvan a lehetősége az őrizetbe vételre. A prostitúció jogi definíciójának a fizetség ellenében megvalósuló befejezett szexuális szolgáltatásra kellene korlátozódnia. A cikk szerzőjének végkövetkeztetése, hogy a fedett rendőrségi eljárást a prostitúció bizonyítása esetében tiltani kell, mivel az sérti a gyanúsítottak méltányos eljáráshoz való jogát.

\section{Felhasznált irodalom}

Del Valle Torres, P. (2020). Sexual Contact Between a Suspect and Police Officers: How Far Should Police Go to Prove Prostitution? American University Journal of Gender, Social Policy \& the Law, 28(3), 471-492.

\section{Lippai Zsolt}

Rendőrségi szakértelem és erő alkalmazása: kezdő és gyakorlott rendőrök intézkedési döntéshozatalának vegyes módszerü vizsgálata

\section{Use of police expertise and force: a mixed approach to the decision- making of novice and experienced police officers}

Laura Mangels, Joel Suss és Brian Lande tanulmánya az Amerikai Egyesült Államok (továbbiakban: USA) Igazságügyi Minisztériuma által finanszírozott erőszakellenes projekt részét képező - kognitív regressziós és természetes nyelvi feldolgozási technikákat kombináló - kutatás eredményét mutatja be. Célként a rendőri állomány hatékony módszertani képzésének javítását jelölték meg. 
A kutatás bizonyítja a rendőri szakértelem és erőszak alkalmazása között kimutatható oksági kapcsolatokat. A magasabb szaktudás nagyobb garanciát nyújt a hatósági erőszak jogszerüségének biztosításához, az erőszakkerülő szakmai kultúra kialakításához.

A szerzők a sokrétü és speciális szakmai tudást igénylő rendőri tevékenységekkel kapcsolatos korábbi tudományos kutatások eredményeit elemezve megállapítják, hogy a rendőri szolgálatellátás hatékonyságnak objektív mérésére a szakmaiság képzettségi szint szerinti meghatározását kivéve - kevés módszer létezik. A helyes döntéshozatal értékelése önmagában sejlő nehézséget jelent, különös tekintettel a rendőri állomány eltérő szintủ szakmai felkészültségére és tapasztalatára.

A módszertani megközelítésben robosztus gyakorlati példatömegre támaszkodó és viszonylag alacsony költségvonzatúnak jelölt kutatásban önkéntes jelentkezés alapján 36 fó (a 26 hetes alapkiképzés befejezése elött álló) újonc és 42 fő (többnyire oktatói, kiképzői munkakört is ellátó) tapasztalt rendőr vett részt. Befektetett idejükért cserében - ajándékkártyák formájában - anyagi kompenzációban részesültek.

Az online felmérés résztvevői az USA különböző helyszínein testkamerával rögzített öt (1. Fort Collins, Colorado; 2. Tulsa, Oklahoma; 3. Palestine, Texas; 4. Miami-Dade, Florida; 5. Springfield, Missouri) egyforma sorrendü, valós rendőri intézkedés felvételeit elemezték. A tényleges intézkedésről készült felvételeket utóbb a részt vevők bevonásával, didaktikai célból, részletesen feldolgozták. Az intézkedési folyamat három fázisában a felvétel lejátszását megszakították annak érdekében, hogy a lehetséges döntési alternatívákra rámutassanak. A megállításokat döntési pontként jelölték meg, ahol a részt vevőknek az intézkedési szituációkkal kapcsolatos kérdésekre kellett válaszolniuk. A kutatási kérdések elemzésének szempontrendszere kiterjedt az abban részt vevők iskolai végzettségére, katonai múltjára, szolgálati idejére, szakmai tapasztalatára, nemi hovatartozására, intézkedési szóhasználatára, az intézkedések során megjelenő verbális technikákra, a nyelvi mintákra és azok előfordulási gyakoriságára, illetőleg a rendőri erő alkalmazásával kapcsolatos döntéshozatali mechanizmusokra. Az összesített szövegértékelés céljaként pedig az erőszakmentes rendőri intézkedések támogatását jelölték meg. Azt vizsgálták, hogy milyen felkészültség, szaktudás és verbális képességek szükségesek ahhoz, hogy ezek kifejlesztése a rendőri szaktudás részévé válhasson.

Kutatási módszereik és megállapításaik lehetővé teszik azt, hogy a kezdő rendőrök képzésében hangsúlyt kapjanak olyan verbális metodikák, amelyek az eredményes és erőszakmentes intézkedési készségek kialakításához nélkülözhetetlenek. Laura Mangels, Joel Suss és Brian Lande tanulmányában 
megfogalmazott kutatási eredmények meggyőzőek. Természetesen további kiegészítő kutatásokra van szükség annak feltárására, hogy megállapításaik valóban alkalmasak a szakértelem növelésére, figyelemmel a rendőri szervezetek specifikumaira és az egyes területek sajátosságaira.

\section{Felhasznált irodalom}

Mangels, L., Suss, J. \& Lande, B. (2020). Police Expertise and Use of Force: Using a Mixed-Methods Approach to Model Expert and Novice Use-of-Force Decision-Making. Journal of Police and Criminal Psychology, 35(3), szám, 294-303. https://doi.org/10.1007/s11896-020-09364-4

\section{Pászti Péter Gergely}

\section{A letartóztatás rendeltetése és az alternatívák szükségessége}

\section{The purpose of the arrest and the need for alternatives}

Ebben a tanulmányban Adriano Martufi és Christina Peristeridou az elözetes letartóztatásra vonatkozó ECHR (European Convention of Human Rights, az Emberi Jogok Európai Egyezménye) szabályokat vizsgálja, leginkább az ilyen jellegü fogva tartások legitim alkalmazására fókuszálva. Ezek a szabályok az előzetes letartóztatás Európa szerte elharapódzott túlzott használatának visszaszorításában játszhatnak fontos szerepet. A szerzők az ECHR szabályok hiányosságainak elemzésével ahhoz kívánnak segítséget nyújtani, hogy a későbbiekben megelőzhető legyen a visszaélésszerü fogva tartás. Emellett rámutatnak az ártatlanság vélelmével kapcsolatos ellentmondásokra is.

Az elmúlt években az egész világon több kutatás foglalkozott az előzetes letartóztatás sokszor hibás vagy túlzott használatával, és az ezekből adódó, az adott személyt vagy a vele kapcsolatos eljárást negatívan érintő hatásokkal. A statisztikák szerint minden negyedik fogva tartott személy előzetesben van, és a bíróságok, mivel a szerzők szerint teljesen bizalmatlanok a lehetséges hatásukkal kapcsolatban, szinte egyáltalán nem használnak olyan alternatív büntetéseket, mint például az elektronikus megfigyelés, a feltétel nélküli vizsgálati fogság vagy bármely olyan megoldás, amely kevésbé szigorúan szabályozza az alperes életét a vizsgálat és a tárgyalás alatt. Ebben az írásban a szerzők górcső alá veszik az előzetes letartóztatás és az alternatív intézkedések igazi céljait. A tradicionális hozzáállás szerint a tárgyalás elötti elzárás, amelyet a „cél szentesíti az eszközt” felfogás tesz teljesen elfogadottá, mindig bizonyos következményekkel jár, ezért - mint arra 
a különböző kutatások is rámutatnak - ebből az következik, hogy a fogva tartást mindig kockázatorientált intézkedésnek kell tekinteni. A szerzők a bírósági gyakorlata során kidolgozott célokra koncentrálva kifejtik, hogy a kockázatorientált megközelítésnek erős elvi érveléshez kell kötődnie. Ezt a megközelítést szem elött tartva vetik kritikai analízis alá az ECHR szabványokat.

Martufi és Peristeridou a publikációjukban bemutatják, hogy az ECHR normák mennyire képesek a visszaélésszerủ és túlzott fogva tartás visszaszorítására. Az ECHR nemzeti szinten való müködésével és logikájával kapcsolatos kritikus véleményüket négy fő ponttal támasztják alá. Elöször is, az ECHR szabványok sok esetben alkalmazhatatlanok, és így túl sok mérlegelési jogkört hagynak a nemzeti hatóságokra. Másodszor, néhány területen nincs megfelelően alkalmazva, a szerzők szerint még mindig eléggé pontatlanul meghatározott ,ártatlanság vélelme” fogalom. Harmadszor, a nemzeti jogban az előzetes letartóztatás céljai különböző eredetre vezethető vissza, és így felveti azt a problémát, hogy az ECHR szabványok nem általánosíthatók, vagyis nem vonatkoztathatók valamennyi jogesetre. Negyedszer, az ECtHR (Europeaan Court of Human Rights) nem ad egyértelmü iránymutatást az előzetes letartóztatást helyettesítő alternatív intézkedések alkalmazásához. A lehetséges alternatívák nem rendelkeznek koherens jogi normákkal, mivel nincsenek az egyezményben pontosan meghatározva ezeknek a keretei. A szerzők úgy gondolják, hogy az elózetes letartóztatási normák harmonizálására irányuló bármely kísérlet, az ECHR szabványok kritikus elfogadásának és fejlesztésének hiányában, nagy eséllyel, eleve kudarcra van ítélve. Martufi és Peristeridou összefoglalásként kijelentik, hogy ha az EU tökéletesíteni akarná az előzetes letartóztatás ésszerü alkalmazását, vagyis, hogy az előzetes letartóztatás legyen a kivételes megoldás, akkor nem lenne szabad ennek biztosítását egyedül az ECHR normákra szükíteni.

\section{Felhasznált irodalom}

Martufi, A. \& Peristeridou, C. (2020). The Purposes of Pre-Trial Detention and the Quest for Alternatives, European Journal of Crime, Criminal Law, and Criminal Justice, 28(2), 153-174. https://doi.org/10.1163/15718174-bja10002

\section{A cikk APA szabály szerinti hivatkozása}

Beke J., Cieleszky P., Nagy I., Fejes A., Rompos É., Kalmár Á., Urbán F., Lippai Zs. \& Pászti P. G. (2021). Nemzetközi Rendészeti Figyelő II. Belügyi Szemle, 69(6),1045-1068. https:// doi.org/10.38146/BSZ.2021.6.7 